\title{
Knowledge governance, innovation and development
}

\section{LEONARDO BURLAMAQUI*}

This paper aims to be a very preliminary effort to contribute to a better understanding of the interaction among innovation, competition and intellectual property policies from an evolutionary-developmental perspective. As such, it seeks to build a more coherent framework within which the discussions of both institution building and policy design for development can proceed. In order to accomplish that, the paper introduces the concept of "Knowledge Governance" as an alternative analytical and policy-oriented approach, and suggests that from a public policy/public interest perspective, and within an evolutionary framework, it is a better way to address the problems concerning the production, appropriability and diffusion of knowledge. In doing so, it also intends contribute to broaden the ongoing discussions on the "New Developmentalism”.

Keywords: globalization; governance; competition; intellectual property; antitrust.

JEL Classification: G18; H 44; O4; K21.

\section{INTRODUCTION}

To the question "where do knowledge and innovations come from in the developed nations?" a very large part of the answer would include: publicly funded $R \& D$, government contracting to buy things from the private sector that do not exist, using competition policies to disseminate those innovations - and to squeeze productivity gains from the process — and using the WTO to help open up markets for those innovations abroad (Block, 2008; Weiss, 2008, 2009). In

\footnotetext{
* Program officer at the Ford Foundation (NY) and Associate Professor of Economics at the State University of Rio de Janeiro. E-mail: 1.burlamaqui@fordfound.org. I would like to thank Neil Netanel for the excellent suggestions concerning both form and content for a previous version of this paper. The paper represents my own personal views, and does not reflect those of the Ford Foundation.
} 
the case of the US, armed with an annual procurement budget of $\$ 450$ billion - more than 1 trillion if states are included - the US state plays a crucial role in governing the way knowledge and innovations are produced and commercialized (Ruttan, 2006; Weiss, 2009).In that environment, it is accurate to say intellectual property rules and regulations still play an important role in shaping up the incentive system for producing knowledge. But it is equally important to recognize they are not the linchpin of innovation policy, technological development or competiveness building, but part of a much broader system within which the governance of knowledge takes place. This is an extremely important lesson the most technologically developed nation has to offer the less developed ones, and from the perspective of crafting development strategies, probably the most valuable one. $^{1}$

Largely because of the work of Richard Nelson and his collaborators, a "National System of Innovation" approach to policymaking was developed and is revealing itself to be extremely useful in evaluating innovation policies (Nelson, 1993, 2005; Kim and Nelson, 2000). However, when it comes to intellectual property and to the subtleties of the interaction among law, economics and the governance of technological development, the available perspectives at hand still fail to give us a comprehensive approach to either policy making or institutional building. On the dominating, neoclassical, front, the new developments on the intellectual property front include a whole wave of claims about extending monopoly positions and market power (the right to patent generic knowledge, business models, etc. - cf. Merger, 2003; Landes and Posner, 2003.) to leading firms, thereby protecting them from competition - or, to put it in mainstream language, these claims are designed to create or reinforce market failures in the sense of shielding firms from competition instead of exposing them to it. ${ }^{2}$

For those of us to which this is not a sound approach to start from, a central question naturally unfolds: How should intellectual property rules and regulations interact with competition policies, publicly funded R\&D and other forms of technology policy in order to help craft development strategies? It appears there is no coherent analytical framework to address that interaction. ${ }^{3}$ But those links are

\footnotetext{
${ }^{1}$ The present paper is an outgrow of recent papers published by the author (Burlamaqui, 2009a, 2009b).

${ }^{2}$ See Arnold Plant's point below on that matter.

${ }^{3}$ This does not imply a shortage of work discussing specific issues in what is called "the economics of intellectual property rights.” See Menell, 1999, for an excellent survey on general theories of IP. A very interesting review acknowledging the under-researched nature of the theme can be found in Dixon and Greenlalgh, 2002. The shortcomings of most of that work are, from my perspective, the result of its concentration on "data," "measures," and "testing," with little attention paid to the theoretical framework within which they are conducted.
} 
central to any meaningful discussion of both dynamic competition and development in a global context today.

This paper aims to be a very preliminary effort to contribute to a better understanding of the interaction among innovation, competition and intellectual property policies from an evolutionary-developmental perspective. As such, it seeks to build a more coherent framework within which the discussions of both institution building and policy design for development can proceed. ${ }^{4,5}$ We will label it a "Knowledge Governance" approach and suggest that from a public policy/public interest perspective, and within an evolutionary framework, it is a better way to address the problems concerning the production, appropriability and diffusion of knowledge. ${ }^{6}$

The chapter is structured as follows: after this brief introduction, second section attempts to link dynamic competition with intellectual property issues from the perspective of the dynamic efficiencies and inefficiencies that are bound to appear. Trhird section broadens the discussion by introducing the concept of a "market-features approach" conceived as a more suitable one than the market-failures approach for structuring knowledge governance policies from an evolutionary perspective. Fourth section further develops the previous framework by linking market features, competition and technology policies with intellectual property. Special attention is given to how competition policies should address intellectual property issues under a market-features approach, as well as to the institutional design of public agencies dealing with intellectual property issues. Fifth section concludes the paper by suggesting some policy implications of that "knowledge governance" approach.

\footnotetext{
${ }^{4}$ Incidentally, it should contribute, as well, to broadening the Schumpeterian research agenda by directing it into a scarcely explored (in the Schumpeterian domain) territory: that of "law and economics.” But see Langlois, 2001, for an interesting starting point in that direction.

${ }^{5}$ F. Scherer $(1994,1996)$ has dealt consistently with these issues but, we argue, in a much more structure-conduct-performance approach than in a genuinely Schumpeterian one. The neo-Schumpeterian legacy has dealt heavily on competition policies (or how to enforce competition) but has said very little on the relationship among innovation, intellectual property regimes, business cooperation, and abuses of economic power.

${ }^{6}$ Knowledge governance is a broad concept which embraces different forms of governance mechanisms influencing the production, appropriability and dissemination knowledge. As a provisional definition, the "knowledge governance approach" is characterized as a distinctive, emerging approach that cuts across the fields of knowledge management, organization studies, and innovation and competition policies. Knowledge governance is taken up with how the deployment of governance mechanisms influences knowledge processes, such as sharing, retaining and creating knowledge". "As an analytical perspective, it encompasses intellectual property rules and regulations but supersedes it by drawing on those fields and disciplines in order to identify the contours of the new knowledge ecology, and to support alternative governance mechanisms for organizational and business models which are emerging as complements - or alternatives - to the instituted intellectual property regime we now have (Burlamaqui, 2009b).
} 


\section{INTELLECTUAL PROPERTY AND DYNAMIC INEFFICIENCIES: THE ROLE FOR KNOWLEDGE GOVERNANCE}

From an Evolutionary perspective, or in the context of Schumpeterian competition, intellectual property rights (IPRs) - patents, trade secrets, confidentiality contracts, copyrights, trademarks, and registered brand names - are powerful, strategic weapons for generating sustained competitive advantages and Schumpeterian and Ricardian rents (cf. Teece, 2001; Jolly and Philpott, 2004). ${ }^{7}$ In the evolutionary economics framework (see Box 1), it is quite clear that in the complete absence of legal protection for an invention, the inventor either will have less incentive to innovate or will try to keep his invention secret, thus reducing, in both cases, the stock of knowledge to society as a whole (Landes and Posner, 2003, p. 294).

From an entrepreneurial perspective as well, patents and other IPRs are extremely effective means to reduce uncertainties - and, therefore, to ignite the animal spirits and long-term expectations - through building temporary monopolies around products, processes, market niches, and, eventually, whole markets (Burlamaqui and Proença, 2003; Nelson, 1996). However, the word temporary is crucial here because of creative destruction: as Schumpeter stated long ago, "a monopoly position is in general no cushion to sleep on" (1942, p. 102).

From an intellectual property perspective, patent law ${ }^{8}$ itself internalizes the goal of promoting the diffusion of innovation. It requires, as a condition to granting a patent, that the patent application disclose the steps constituting the invention in sufficient detail to enable readers of the application, if knowledgeable about the relevant technology, to manufacture the patented product themselves. Of course, anyone who wishes to replicate a patented product or process legally will have to negotiate a license with the patentee (Jolly and Philpott, 2004, part 1; Landes and Posner, 2003, pp. 294-295).

Significantly, moreover, any reader of the patent application will be free to "invent around" it: to achieve the technological benefits of the patent by other means without infringing on the patent. Translated to evolutionary-economics jargon, the requirement of public disclosure creates a situation of "incomplete appropriability" for the patent holder, and, therefore, it reinforces Schumpeter's insight on the temporary nature of monopolies: Incomplete appropriability allows for the possibility of technological inventiveness and borrowing from publicized

\footnotetext{
${ }^{7}$ Having said that, it is striking how little has been written about the crucial connection between Schumpeterian competition and IPRs. And, of course, we include ourselves in that loophole. In that regard, legal theorists such as Landes and Posner are clearly ahead, in the sense that they are already doing the reverse track - using Schumpeterian concepts and insights to deal with IPR (cf. Landes and Posner, 2003).

${ }^{8}$ Reference here is to American Patent Law.
} 
information, both of which foster creative destruction processes which are the main challengers of established monopolistic positions.

In sum, intellectual property rights are sources of dynamic efficiencies that can help deliver the Schumpeterian positive-sum game represented by falling costs, falling prices, positive margins (market power), and increased consumer welfare.

\section{Box 1: The Evolutionary Perspective on Economics}

Capitalism is a historical process in which change (and not equilibrium) is the most relevant feature. "Economic change," therefore, should be the object of investigation in an evolutionary research program. ${ }^{9}$

Economic agents are creative, and firms — the main agents — are agents of transformation.

Competition, understood as rivalry among firms and as a selection mechanism, ${ }^{10}$ is the engine that propels economic change.

Innovations, understood as applications of new ideas and/or methods to the economic sphere, are the main fuel of that engine.

Money is an asset, ${ }^{11}$ and markets are sets of financial interrelations and cash flows in which production and distribution are embedded. ${ }^{12}$

The main causal chain in the operation of the economic system runs from the entrepreneurial decisions - expenditure decisions bound to financial commitments and directed to an unknown future - to the determination of the aggregate levels of investment, production, demand, and employment.

Finance and innovations function both as "levers of riches" and as uncertainty creators. Their interplay is at the root of the system's twin operating features: progress and conflict. ${ }^{13}$

Profit rates tend to differentiate (not to equalize ${ }^{14}$ ), and no "proportionality law between investments and profits" applies.

\footnotetext{
${ }^{9}$ This roughly corresponds to Sidney Winter's methodological imperative: "dynamics first" (cf. Winter, 1986).

${ }^{10}$ Although, as Paul David and Brian Arthur have taught us, not necessarily of "best practices."

${ }^{11}$ A "liquidity time-machine," as Davidson uses to call it.

${ }^{12}$ This roughly corresponds to Minsky's "Wall Street” paradigm (cf. Minsky, 1982, chapter 3).

${ }^{13}$ A process wonderfully synthesized in Schumpeter's phrase "creative destruction."

${ }^{14}$ Note that the equalization tendency of the rate of profit is an almost "holy" assumption shared by classical, Marxian, neoclassical, and neo-Ricardian economics. In evolutionary economics, there is neither theoretical basis nor empirical support for holding such an "heroic" assumption. In evolutionary theory, differentiation, not equalization, is the key theoretical outcome.
} 
So much for the basics, but the picture can get much more complicated as we examine the details. When we do that, a considerable policy — and institutional - space opens up for dynamic inefficiencies to emerge and, therefore, for the introduction of governance considerations, and for a knowledge governance approach. Consider the following five observations.

First, as Arnold Plant, an almost forgotten analyst in the field, observed in the early 1930s, "In the case of physical property, the institution of private property makes for the preservation of scarce goods. [...] In contrast, property rights in patents and copyrights make possible the creation of scarcity of the products appropriated. [...] the beneficiary is made the owner of the entire supply of a product for which there may be no easily obtainable substitute" (Plant, 1974 [1934], pp. 65-67, emphasis added). In sum, intellectual property regulations can easily give rise to dynamic inefficiencies, ${ }^{15}$ and that alone leaves ground for knowledge governance-oriented initiatives ${ }^{16}$ to enter the scene, as we will see shortly.

Second, the broader the patent protection (and IPRs, generally), the less the patentee's competitors will be able to benefit from the patent by "inventing around," or innovating on the shoulders of, the patent- (or copyright-) holder. Broad IPRs are thus bound to exacerbate the dynamic efficiencies that Plant and others have observed. Accordingly, especially given the complexity and diversity of patents and other IPRs, a one-size-fits-all prescription seems ill-advised. Competition policies ${ }^{17}$ surely have a place in limiting IPR scope, if their main goal is innovation diffusion and not innovator's protection per se.

Third, both innovation and competition policies must address the practice of strategic patenting, that is, the proliferating business strategy of applying for patents that the company has no intention to use, or exploit, solely to prevent others from profiting from the innovation (cf. Varian, Farrel, and Shapiro, 2004, part 2; and Landes and Posner, 2003, chapter 11). Obviously this is a major source of dynamic inefficiency. It has the effect of draining resources from true innovative activity (or, from labs to courts). It drastically increases the costs of patent prosecution and litigation and, therefore, of innovation. Such strategic patenting constitutes a paradigmatic example of what Baumol has called "unproductive entrepreneurship.” As Baumol notes:

“[...] [a] variety of roles among which the entrepreneur's efforts can be reallocated [...] and some of those roles do not follow the constructive and innovative script conventionally attributed to that person. Indeed, at

\footnotetext{
${ }^{15}$ Meaning the expected (negative) impact on future incentives for competitors to compete (innovate) and future consumer welfare. (See Anthony, 2003, section IV.)

${ }^{16}$ Both on policy on the institutional building.

${ }^{17}$ We will use the term "competition policies" rather than "antitrust" here because of the outdated connotation of the latter. We will not be discussing "trust-busting," but a much more subtle and complex set of behaviors, institutions, and policy tools.
} 
times the entrepreneur may even lead a parasitical existence that is actually damaging to the economy (cf. Baumol, 1993, chapter 2, p. 25; see also chapter 4$)$ "

Evidently, this task of "reallocation of entrepreneurship" (from unproductive roles to productive ones) is a knowledge governance matter as well as an institutional-design task in the junction of competition policy and intellectual property management.

Fourth, IPRs have a central role in the "new economy" (or "digitally renewed" economy, as Paul David would more precisely label it). ${ }^{18}$ In so-called "new-economy industries," intellectual property, rather than the products and processes in and of themselves, is a firm's primary output or asset. Overlapping innovations, rapidly falling average total costs, zero marginal costs, strong network externalities and, therefore, fierce "standards battles" and path dependence are the hallmarks of new-economy industries (Shapiro and Varian, 1999; Best, 2001; De Long, 2000; Brynjolfsson and Kahin, 2002). These market characteristics might be seen to generate speeding waves of creative destruction and, thus, potentially more (not less) fiercely competitive challenges to incumbents. Although there is an element of truth in that picture, creative destruction in a world of increasing returns of scale, fast learning, and "winner-take-all" markets does not mean anything close to some idealized form of "perfect competition" or perfectly contestable markets. Rather, it merely brings the replacement of one, or a few, dominant firms by others, such as the replacement of Fairchild by Intel, of Wang and Compaq by Dell and HP, and of IBM by Microsoft.

In the new economy, in other words, firms' abilities to combine first-mover advantages with trade secrets, patents, copyrights, brand loyalties, and network externalities may afford them secure monopolistic positions despite their low rate of (radical) innovations and not because of it. ${ }^{19}$ There is an obvious role for knowledge governance here. However, the normative policy framework within which it should take place is far from certain. We will revisit it in section IV.

Fifth, if we think of innovation as a cumulative process in which cutting-edge knowledge and know-how rest on previous innovations, and of patents and IPRs, in general, as fences erected to protect those previous innovations, it is not difficult to perceive, depending on the institutional design within which IPRs are handled,

\footnotetext{
${ }^{18}$ Cf. David in Brynjolfsson and Kahin, 2002, p. 85.

${ }^{19}$ See Landes and Posner's somehow reluctant recognition of that point (pp. 395-96). The case of Microsoft itself can be used to illustrate the point. The lack of breakthroughs - technological innovations, or radical quality-price improvements - is notoriously known in Microsoft. It is well known that the "Windows" model was copied from Apple's user interface - which itself was a second-hand theft from Xerox PARC - as well as the tremendous lack of perception, by the company, of the Internet potential until the success of Netscape became obvious. It is also known that the differences between the versions of Windows and Office that I'm using right now, although "new," display very pale improvements in relation to their 1998 predecessors.
} 
the tension and potential trade-off between private and public interests. This is the so-called argument of the "second enclosure movement" or "information feudalism" which is now the subject of intense debate (cf. Drahos and Braithwaite, 2002; Boyle, 2003; Evans, 2005; Technology Review, 2005). According to Evans (discussing Boyle's ideas),

"There are really two halves to the second-enclosure movement. The defensive side focuses on intensifying the enforcement of protected monopoly rights to exclude others from using information that has been defined as private property. The offensive side of the agenda involves taking information that has been considered part of 'nature,' or the common, cultural and informational heritage of humankind, and transforming it into 'private property.' If both halves are successful, the 'second enclosure movement' would constitute a global re-distribution of property comparable to the eradication of the commons that ushered in agrarian capitalism in Western Europe 300 years ago (2005, p. 2, emphasis added)."

Once more, we encounter strong forces of global dynamic inefficiencies, presenting an opportunity for knowledge governance-oriented policies to step in.

Last, it is necessary to underline the crucial role of the institutional structure - or institutional design - within which IPRs are enforced. We refer here not the rules, as such, but to their legal enforcement apparatuses, the state structures by which they are supported, and the sort of public bureaucracy available to administer the IP system. It is well known in the literatures on institutions and economic sociology that these are crucial elements in determining the degree of success any regulatory system (such as IPRs) can achieve (Evans, 1995; Dobbin, 2004; Smelser and Swedberg, 2005; and Nee and Swedberg, 2005; offer excellent discussions on this theme). Jaffe and Lerner's thoughtful and provocative work on the recent changes in the U.S. patent system (Jaffe and Lerner, 2004) provides background for our discussion of the relationship between the institutional design of the patent system and problems related to the promotion of innovation and "productive entrepreneurship" (section fouth below).

\section{COMPETITION, MARKET FAILURES, AND THE MARKET FEATURES APPROACH}

Competition from an Evolutionary perspective means mainly rivalry. But it also allows room for cooperation. In that realm, competition policies are the regulatory devices used to build a competition-enhancing environment and steer firms' behaviors toward pro-competitive strategies, strategies that include both rivalry and cooperation. As any policy tool, competition policies must be framed against some sort of theoretical background. The most commonly used is the "market-fail- 
ure approach." ${ }^{20}$ But that approach to public policy adds more confusion than clarity to the matter. ${ }^{21}$ It takes the perfect-competition model as its point of departure, yet, if perfect competition is our metric, all markets are laden with market failures requiring correction. And according to which blueprint are we to correct the inevitable failures? Again, it's the perfect-competition model. But where can we find empirical evidence to support that model's relevance for public-policy usage (although there is plenty to reject it)? Or, how can we test this model in order to be assured of its efficiency. (Has anyone ever heard of an actual measurement of a Pareto optimum?) It does not get us very far (For a similar rejection of the market-failure approach to public policy, see Nelson, 2007). ${ }^{22}$

In place of the market-failure approach, and in tune with the knowledge governance - oriented perspective, we proffer a market-features approach. By market-features approach, we mean an analytical perspective that takes into account institutional diversity and sector specificities - in both their technological and industrial dimensions - as well as the regulatory and legal aspects of differentiated degrees of market power. It is a conceptual framework whose main advantage is that it does not fight the empirical evidence but, rather, accommodates it. It does not utilize a one-size-fits-all approach but relies instead on analytical flexibility. And, for our specific subject, it opens space for both sector-specific innovation and competition policies, as well as for differentiated intellectual property rules.

The idea of a market features approach is not new. It comes from that undeservedly neglected tradition that unites scholars such as George Shackle and Ludwig Lachmann, a tradition that could very well be labeled "Austrian Keynesianism" (see Lachmann, 1986, and Vaughn, 1994, on that matter). The specific idea of a market's taxonomy comes from Lachmann's last book in his discussion of markets as economic processes embedded in institutions. As Vaughn explains it, Lachmann argues that:

\footnotetext{
${ }^{20}$ For a clear exposition of that approach, as well as for a public-choice-oriented critique of it, see Mitchell and Simmons, 1994, part 1. Both the Chicago School and its heir, the public-choice perspective, have pioneered the criticisms to that approach by trying to show that most of what was presented by market failures turned out to be children of government failures. But their root is neoliberal in the sense that they stick to the notion of a self-regulated market and with the perfect-competition model as its "proof." Ours will be, instead, an evolutionary-institutionalist-based rejection that will leave spacious room for the "role of the state" in forging competition policies. (See Burlamaqui, 2000, for a more general discussion of that matter.)

21 The paper by Nelson, Dosi, Cimoli, and Stiglitz given at the IPD meeting in Rio (March 17-18) makes the same point but does not pursue, in that work, an alternative theory (Nelson et al., 2005, pp. 2-3).

${ }^{22}$ After all, the perfect-competition model should be an ideal in the Weberian sense of the concept: a construct that accentuates certain properties found in reality and exaggerates them for purposes of organizing and making sense of the empirical data. That means that the construct should be abstract but empirically relevant. The problem is that none of the core assumptions supporting the hypothesis of the model - perfect information, product homogeneity, free entry and exit (absence of sunk costs), price-taking behavior (absence of market power), absence of increasing returns, and tendency toward equilibrium - is found in reality, thus making the model useless either for positive or normative functions - something that Frank Hahn (1984), for instance, spelled out several times in his works.
} 
"Instead of examining the world through the lens of the "market" we need to develop ideal types of particular kinds of markets: assets markets versus production markets, fix-price versus flex-price markets, markets dominated by merchants versus markets dominated by salesmen. Such distinctions will make a difference as to how markets adjust to change (Lachmann, 1986, p. 128, in Vaughn, 1994, p.159, emphasis added)."

This was a brilliant insight, but it was left more or less as it was first submitted. For our concerns, it offers as a very promising alternative point of departure both for positive and normative purposes. Recently, Cimoli and Primi (2007) advanced this insight by developing taxonomy for mapping markets for knowledge.

The table below presents taxonomy of contemporary markets for knowledge according to four main categories: rationale of the market, prevailing patenting behavior, main patent use and barriers to entry. Those markets encompass what in the literature has been identified as market for technologies, plus two additional categories of markets, the market for science and what we have defined secondary markets for science and technology (see Table 1).

These, of course, do not exhaust the possibilities of mapping, but they allow for a much more realistic, although possibly less elegant, assessment of differentiated market workings and how they are likely to adjust (or give rise) to change. That perspective still has to be properly developed, but it will help economic theory to become more relevant and useful from the point of view of understanding empirical reality and crafting policy. It is also in line, for instance, with the recent findings by Carlton and Gertner (2002) in their paper "Intellectual Property, Antitrust and Strategic Behavior," in which they state that "Only detailed study of the industry of concern has the possibility of uncovering reliable relationships between innovation and industry behavior" (p. 30). There is clearly a very promising theoretical road to be traveled here. From an Evolutionary perspective, the market-features perspective should constitute a building block for a knowledge governance oriented approach to public policy.

\section{MARKET FEATURES, KNOWLEDGE GOVERNANCE AND INTELLECTUAL PROPERTY: POLICY AND DEVELOPMENT IMPLICATIONS}

The market-features approach has as its policy counterpart a market-shaping perspective. It is possible, and desirable — through institution building, legal change, and administrative guidance - to redesign market features as well as regulatory mechanisms and proceedings in order to pursue the major public policy goal of promoting and regulating entrepreneurial success. Within that approach, the general rule should be the promotion of innovation plus the assurance of its diffusion, and this implies, again, simultaneously, promoting and regulating entrepreneurial success. Promoting and regulating is a crucial link. Together they address both the 
private (profit-seeking) and the public (innovation-diffusion and technological upgrading) sides of competition policies and their respective institutional designs.

Table 1: A taxonomy of contemporary markets for knowledge

\begin{tabular}{|c|c|c|c|}
\hline \multicolumn{4}{|c|}{ Markets for knowledge } \\
\hline & $\begin{array}{l}\text { Markets for } \\
\text { Technologies }\end{array}$ & Markets for Science & Secondary Markets for S\&T \\
\hline $\begin{array}{l}\text { The } \\
\text { rationale } \\
\text { of the } \\
\text { market }\end{array}$ & $\begin{array}{l}\text { Specificity of technolo- } \\
\text { gies, asymmetries in } \\
\text { routines and com- } \\
\text { petences of agents, } \\
\text { complementarities } \\
\text { between technologies }\end{array}$ & $\begin{array}{l}\text { Increasing } \\
\text { "demand" for } \\
\text { science due to } \\
\text { new technologi- } \\
\text { cal paradigms and } \\
\text { changes in regula- } \\
\text { tory framework }\end{array}$ & $\begin{array}{l}\text { Increasing cumulativeness } \\
\text { and uncertainty in the nature } \\
\text { of technological change } \\
\text { (new tech. paradigms) and } \\
\text { re-shaping of IP systems }\end{array}$ \\
\hline \multirow{3}{*}{$\begin{array}{l}\text { Prevailing } \\
\text { patenting } \\
\text { behavior }\end{array}$} & $\begin{array}{l}\text { Patent to protect, com- } \\
\text { mercialize and diffuse }\end{array}$ & $\begin{array}{l}\text { Patent to protect, } \\
\text { commercialize and } \\
\text { diffuse }\end{array}$ & $\begin{array}{l}\text { Strategic, defensive, blocking } \\
\text { and sleeping patenting. }\end{array}$ \\
\hline & $\begin{array}{l}\text { The value of patents } \\
\text { is related to the subja- } \\
\text { cent technology (pres- } \\
\text { ent or future incorpora- } \\
\text { tion in production) }\end{array}$ & $\begin{array}{l}\text { The value of patents } \\
\text { is related to the sub- } \\
\text { jacent technology } \\
\text { (relevance for further } \\
\text { research or present } \\
\text { or future incorpora- } \\
\text { tion in production }\end{array}$ & $\begin{array}{l}\text { - Patents acquire a value "per- } \\
\text {-se", independently from that } \\
\text { of the subjacent technology. } \\
\text { - The value of patents is, to a } \\
\text { major extent, a function of } \\
\text { expectations regarding future } \\
\text { non-deterministically foresee- } \\
\text { able technological scenarios. } \\
\text { - Patents enter into the asset } \\
\text { portfolio of organizations } \\
\text { as signal of (technological) } \\
\text { reputation. }\end{array}$ \\
\hline & $\begin{array}{l}\text { Technology transfer } \\
\text { through licensing. }\end{array}$ & $\begin{array}{l}\text { Technology transfer } \\
\text { through licensing }\end{array}$ & $\begin{array}{l}\text { Cross-licensing, M\&A, } \\
\text { patent pools, (Liquid market } \\
\text { for knowledge) } \\
\text { Sleeping, blocking, defensive } \\
\text { patenting. } \\
\text { (Derivative market for } \\
\text { knowledge) }\end{array}$ \\
\hline $\begin{array}{l}\text { Barriers } \\
\text { to entry }\end{array}$ & $\begin{array}{l}\text { Technological and } \\
\text { production capacities } \\
\text { (structural) }\end{array}$ & $\begin{array}{l}\text { Scientific capabilities } \\
\text { and technological } \\
\text { capacities (structural) }\end{array}$ & $\begin{array}{l}\text { Size of incumbents, risk- } \\
\text {-propensity, plus scientific, } \\
\text { technological and production } \\
\text { capacities }\end{array}$ \\
\hline
\end{tabular}


Knowledge governance policies should take the market-features approach as their point of departure and should use, extensively, market-shaping devices in order to design policies to manage the creative-destruction process. These policies would seek to shape markets in order to reduce dynamic inefficiencies and increase dynamic efficiencies coming from Schumpeterian competition, a form of competition that uses intellectual property rights as one of its core weapons to instigate competitive conflicts. From the perspective of firms, competition policies should not be about interfering with consolidation or preventing "market power" but should be about preventing "too secure monopolies" - and especially those not based in, and thriving on, higher productivity and superior technological performance.

Knowledge governance policies should be crafted to deal with dynamic market inefficiencies. Plant argued that patents can make the beneficiary "the owner of the entire supply of a product for which there may be no easily obtainable substitute," a troubling claim. A clever, but not radical, innovation (for instance, Post It ${ }^{\circledR}$ notes from $3 \mathrm{M}$ ) should not raise major concerns among policymakers dealing with competition issues. But what about a nascent general-purpose technology (for instance, a new genetic engineering research tool or a particular DNA sequence)? Then Plant's point would hold completely, and the granting of the patent would create substantial monopoly for the owner - and potentially prevent others from exploiting it - thus slowing the diffusion of a new innovation.

More concretely, knowledge governance policies should shape markets and drive firms toward establishing research coordination and patent pools, pushing common standards, preserving multiple sources of experimentation, establishing variable patent and copyrights terms, and severely punishing both "unproductive patenting" behavior and attempts by firms to close markets through creating their own proprietary, closed systems. (See Carlton and Gertner, 2002, for a similar line of reasoning.)

Those examples highlight the importance of the market-shaping approach. In cases like those involving general-purpose technologies, the IPR policy should be much more rigorously examined and carefully constructed. A possible "tool" for dealing with that would be for the government to claim a golden share in the IPR system (especially patents and copyrights), by which it would be able to convert a property right previously granted ${ }^{23}$ into a general public license should the owner refuse, after establishing his first-mover advantage, ${ }^{24}$ to behave cooperatively and to license broadly and fairly.

\footnotetext{
${ }^{23}$ That is, a legally enforced temporary monopoly.

${ }^{24}$ Meaning being able to recover his costs, establish a robust competitive advantage, and enjoy a sizable profit stream, but not being able to exclude others from using and inventing around his innovation or protecting its diffusion. Taking as an example the Microsoft case, the battle shouldn't be about "breaking" the company. The golden share would allow the government to force Microsoft to publish its source code. An open code would quickly get cleaned up and improved, consumers would benefit,
} 
In sum, radical innovations - and, especially, general-purpose technologies - should be subjected to a special IPR regime in which the government's administrative guidance should be able, if needed, to "shape" the market toward a more competitive institutional design (away from too secure - even if temporary monopolies). A legitimate, and fair, reason to do so is that, according to some recent studies, the US government played a decisive part in the development of virtually all general-purpose technology, from interchangeable parts and mass production to Darpa ${ }^{25}$ and biotech (cf. Ruttan, 2006; Weiss, 2007; Block, 2008). Having financed the bulk of the basic R\&D that enabled the emergence of champions such as Boeing, General Electric, IBM, and a whole host of high-tech giants in hardware, software, and biotech, it would not be unreasonable for the US government - or any other government, by the way - to have a stronger role in granting that technological achievements don't remain overly protected and scarcely diffused (cf. Roland, 2002; Fong 2000).

In fact, this is already in the EU Competition Commission's radar. Its former chief, Neelie Kroes, has recently argued in a speech that

“ industry standards for technology could be based on either proprietary or non-proprietary technologies, but when a market developed so that a proprietary technology became a de facto standard and the owner of that technology exploited that market power, competition authorities might have to intervene. One remedy would be to require disclosing of information at 'fair rates' so that other companies could design compatible products and systems" (Financial Times, June, 11, 2008).

But overall, although in other countries the privatization of publicly generated knowledge is not as acute as in the contemporary United States, the US PTO is certainly setting standards for everyone else. The way we have it now, its "public virtues, private vices," an inversion of Mandeville's dictum.

Given both the complexity and diversity of patents and IPRs, in general, a one-size-fits-all prescription is perhaps not the best way to handle the matter. The 20 -year length of a patent (or the terms of copyrights and registrations) is certainly not a "scientifically established outcome" (Landes and Posner, 2003). It is, rather, a convention - that is, an institutional-legal construct that, as such, can very well be questioned and changed. ${ }^{26}$ Conversely, as Jaffe and Lerner adduce (very

and new entrants would probably arise helping ignite the innovation race and dislodging Microsoft from its monopoly position while preserving the company's market power and ability to innovate.

${ }^{25}$ DARPA is the Defense Advanced Research Projects Agency, the central research organization of the United States Department of Defense. Its most radical innovation was the Internet (known first as "DARPA-Net").

${ }^{26}$ As a matter of fact, a century ago, copyrights lasted for 14 years - and could be extended another 14 if the copyright holder petitioned for an extension. Today, corporate copyrights last for 95 years, and individuals retain copyrights for 70 years after their deaths. There was nothing "scientific" to back 
much in line with the market features approach), "In the world of theoretical patent analysis, it is easy to show that the attributes of patent protection should vary depending on the characteristics of the technology" (p. 203).

But Jaffe and Lerner then expose several reasons why this differential-treatment approach would not work in practical terms (pp. 203-205). The difficulties of dealing with technologies - classifying and quantifying their impact empirically — plus the political lobbying by firms to get special treatment are the main arguments submitted by the authors. We are in partial agreement with them as to having pure technological considerations serving as the basis for policy, as well as to the rent-seeking dangers surrounding any sort of differential treatment. But note that if we look to the development histories of Japan, South Korea, Singapore, China, Ireland, or the United States, differential treatment lay at the core of both their technological and industrial policies. That is, it can work (cf. Chang, 2002; Reinert, 2007; Austin, 2009).

To be less abstract on the matter, let us propose this broad guideline for knowledge governance policies: the length and breadth of patent protection, as well as innovations protected by copyrights, such as software, should be linked to the expenditures in R\&D, made or budgeted ${ }^{27}$ by applicants. Thus, big research budgets (in terms relative to the firm's size) would, in principle, qualify better than "historical accidents" to earn legitimate protection. Instead of one size fitting all, we would have something like - paraphrasing Rodrik — "Many recipes under the same rule. ${ }^{28}$

The third source of dynamic inefficiencies referred to above, strategic patenting, should be dealt with in a somewhat Ricardian way: ${ }^{29}$ earned but unused patents should be classified like fertile but uncultivated pieces of land in an environment structurally constrained by scarcity. They should be taxed, and progressively so. After an initial "launching period," each year of idleness in the commercialization of the patent should give rise to a severe fine, the exact amount of which should be

these changes but rather the powerful lobby of the entertainment industry. As for patents, mind the reader that both in Switzerland (between 1850 and 1907) and in the Netherlands (between 1868 and 1912), industrialization occurred without enforcement of patent laws (cf. Schiff, 1971).

${ }^{27} \mathrm{R} \& \mathrm{D}$ expenses as a percentage of the applicant's sales or assets, assuming that those R\&D-intensive industries are also the ones bearing more fixed and sunk costs, plus near-future planned expenses tied to the "birth" of an innovation or technology, should be in the contract granting the rights and their actual production of the enabling mechanism to conclude the exam. Otherwise, patent pending would be a sort of "reasonable doubt" proviso.

${ }^{28}$ A very difficult, emerging theme here is the protection to be given to traditional knowledge: DOC (Denominacione de Origine Controllata certifications that grant monopolies based on regional know-how and capabilities, like champagne versus sparkling wines) issues and related others. We acknowledge its importance but do not deal with that in this paper.

${ }^{29}$ The parallel here would be between the example given by David Ricardo of the unique fertility of a piece of privately owned land, which would generate increasing revenues to its owner, regardless of efforts to improve the land's productivity, and the stream of revenue generated from a patent regardless of whether its owner keeps innovating. 
figured out by specialists in the field but could very well be an increasing percentage of the patentee's sales or assets. Rigorous? Yes, but patents and IPRs, in general, are subjects of public interest. They are too important to be left to markets and lawyers to craft. Additionally, the kind of approach to the governance of knowledge we are suggesting should have as its core principle, the discouragement of the sort of unproductive entrepreneurship that Baumol has been talking about for more than a decade, a type of legal entrepreneurship that turns law firms into very big and profitable corporations but with zero impact on the economy's real productivity. It would, in sum, help to trigger the "relocation of entrepreneurship" - from courts back to labs - as claimed by Baumol.

The fourth point outlined (in second section above) relates to the relationship between the "digitally renewed economy" and intellectual property issues, and particularly to the risk of winner-take-all market outcomes or, from the point of view of firms, to locking out competitors via the combination of increasing returns, network externalities, path dependency, and stronger IPRs protection (cf. Varian, Farrel, and Shapiro, 2004; Carlton and Gertner, 2002). Knowledge governance policies here should pursue, very aggressively if needed, public subsidization of standards development, cooperative standards setting, stimulus of (instead of restriction on) joint-research ventures and other forms of research coordination (Carlton and Gertner 2002, pp. 3-7) and venture-capital financing to multiple sources of experimentation (Bartzokas and Mani, 2004). The aim should be a "less kind, less gentle patent system," as Jaffe and Lerner (2003) put it, in which patents are much harder to acquire and relatively easier to share.

Also of concern is the recent wave of IPR expansion and its connection to a potential "information feudalism" or "second enclosure movement." This movement is seen by the so-called "progressive IP lawyers," software programmers, and a sizable number of social and natural scientists of various extractions as a recipe for global monopoly, one that is likely to stifle innovation at the same time it concentrates wealth (see Moglen, 2003; Benkler, 2003; and Evans, 2005). A number of commentators have called for an alternative to this second enclosure, an alternative they term "the new commons." ${ }^{30}$ As Evans has aptly put it, this alternative is "attractive both because of its distributional implications and because of its potential for raising the rate of innovation and value creation" $(2005$, p. 3). From a knowledge governance perspective, the basis of the new commons comes from a redefinition of "ownership": from the focus on the right to exclude to the focus on the commitment to distribute (disseminate).

The key idea here is that once property rights are redefined along the lines pioneered by the open-source software movement, a much more egalitarian redis-

\footnotetext{
${ }^{30} \mathrm{~A}$ "commons" is a piece of land over which people can exercise certain traditional rights in common, such as allowing their livestock to graze upon it. Older texts use the word "common" to denote any such right, but more modern usage is to refer to particular rights of common and to reserve the name "common" for the land over which the rights are exercised. By extension, the term "commons" has come to be applied to other resources that a community has rights or access to.
} 
tribution of intangible assets and a more powerful rationale to foster innovations will be able to emerge. This rationale is one that unfolds from the characteristics of the networked information economy - an economy of information, knowledge, and culture that flows over a ubiquitous, decentralized network. In that environment, as Benkler remarks, productivity and growth can be sustained in a pattern that differs fundamentally from the industrial information economy of the 20th century in two crucial characteristics. First, non-market production can play a much more important role than it could in the physical economy. Individuals working alongside firms can make a real difference in the creation of innovative solutions and productivity gains (Benkler, 2003, p. 1, and 2006). ${ }^{31}$ Second, radically decentralized production and distribution, whether market-based or not, can similarly play a much more important role by increasing the diversity of ways of organizing production and consumption and, therefore, by increasing the sources and possibilities for multiple forms of experimentation.

This is clearly a global issue and - because of its global scope, and also because of the under theorized relationship between innovation, competition policies and intellectual property rights - a very difficult one to handle. It will certainly require the active involvement of governments in encouraging and assisting the development of open-source systems to move society toward more general-public-licenses-oriented IPR regimes. It will also require international cooperation both very turbulent matters from a power-politics perspective. Nevertheless, the recent decisions by IBM and Nokia, for example, to put part of their patents into the public domain suggests that there is perhaps more room to maneuver than the skeptical analyst might expect.

Finally, the crucial role of the institutional structure - or institutional design - within which the IPRs are enforced must be examined. This brings us to Jaffe and Lerner's (2004) discussion of the recent institutional-design changes in the US patent system and its deleterious effects on innovation. ${ }^{32}$ Their story unfolds around two fundamental changes in the legal-institutional foundations of the system. The first, in 1982, was a change in the process by which patent cases were handled. From then on, instead of the 12 regional courts of appeal, one single, specialized appeals court began to process all appeals in patent cases: the Court of Appeals for the Federal Circuit (CAFC). Consolidating patent appeals in one court had the salutary effect of injecting homogeneity into a fragmented system. However, because the CAFC's formative years coincided with the "Japanese challenge," "America's lost competitiveness," and the Reagan administration's extreme pro-business

\footnotetext{
${ }^{31}$ And, he adds, one can clearly observe this behavior by noticing that most of what we do on the Internet runs on software produced by tens of thousands of volunteers, working together in a way that is fundamentally more closely related to a community than to a hierarchical big corporation standing alone.

${ }^{32}$ Why do we want to illustrate that point with the US system? Because, simply, it is the most powerful patent system in the world and also the most likely to be mimicked by "emergent economies."
} 
policies, the new homogeneity took the form of interpreting patent law "to make it easier to get, easier to enforce patents against others, easier to get large financial awards from such enforcement, and harder for those accused of infringing patents to challenge the patents' validity" (Jaffe and Lerner, 2004; Weiss, 2008).

The second change dates from the early 1990s, when Congress modified the Patent and Trademark Office's (PTO) financial basis, turning it into a profit center, a service agency whose costs of operation should be covered by the fees paid by patent applicants - or by its clients (id.).

According to Jaffe and Lerner, these two changes transformed a regime that had been committed to fostering and protecting innovation into a lawyers' paradise. The patent system then became a very powerful generator of unproductive entrepreneurship and, hence, a severely dysfunctional institution. In order to be "efficient," the PTO started to examine - and grant — as many patents as it could, regardless of the quality and reliability of the examination process. Between 1983 and 2006, the patents granted increased from about 62,000 to 196,000 per year. The number of patent applications also ballooned to 452,633 in 2006 (from 112,040 in 1983). ${ }^{33}$

In analytical terms, what happened was the replacement of a qualified bureaucracy committed to public service by a business-oriented "new public management" cadre that was given the task of regulating a crucially important part of the knowledge-creation system of the new economy. ${ }^{34}$ The results were dismal in that they incentivized strategic patenting and patent litigation (which consumes literally billions of dollars) without any clear impact in terms of innovation inducement or on the rate of innovation (see Noll, 2004, on this issue). In sum, the economic benefits of stronger patent protection and increased room for strategic patenting have failed to materialize - except in the big patent-portfolio holders' licensing revenues and on the dedicated law firm's balance sheets. On the sort of detailed institutional redesign which ought to be done in order to improve patent quality in the United States, I direct the reader to the excellent discussion by Jaffe and Lerner (2004).

Patents and intellectual property in general are too important to be left to lawyers, juries, and a single PTO. They should be institutionally restructured, in the form of a cross-cutting knowledge governance agency in charge of coordinating publicly funded R\&D with innovation policies, competition policies and IPRs. ${ }^{35}$

\footnotetext{
${ }^{33}$ Cf. http://www.uspto.gov/go/taf/us_stat.htm.

${ }^{34}$ As Drechsler aptly sums it, NPM is the transfer of business and market principles and management techniques from the private into the public sector, symbiotic with and based on a neoliberal understanding of state and economy. The goal, therefore, is a slim, reduced, minimal state in which any public activity is decreased and, if at all, exercised according to business principles of efficiency. NPM is based on the understanding that all human behavior is motivated by self-interest and, specifically, profit maximization (cf. 2005, p. 1).

${ }^{35}$ Note that in the field of technology procurement, the network of US agencies already includes, today, the Department of Defense, the CIA, NASA, the Department of Energy, the National institutes of
} 
Dedicated judges and courts (but not juries) should be the "last resort" in those matters, not the first.

Additionally, this agency should be structured along "Weberian lines" — a set of offices in which appointed civil servants operate under the principles of merit selection, expertise, hierarchy, the division of labor, exclusive employment, career advancement, and legality. This type of rationality - Weber's key term - would increase speed, scope, predictability, and cost-effectiveness (Weber 1922, pp. 124130; Drechsler 2005).

\section{CONCLUSION}

The knowledge governance oriented policy-institutions framework we have proposed should be flexible and pragmatic and should have creative-destruction management as its main goal. In its innovation and competition-policies dimension, it should not be anti-consolidation but anti-unproductive entrepreneurship (Baumol 1993 and 2002); pro-efficiency but not libertarian (in the "Chicago School" sense of letting the market, almost always, take care of its own problems); and, especially, pro-cooperation, leaving room for business networks to thrive and for state-sponsored administrative-guidance initiatives. It should also engineer policies toward the development of multiple sources of experimentation and allow room for industrial and technology policies without jeopardizing its own core theoretical foundations.

In its intellectual property dimension, it should not point to a one-size-fits-all institutional design ${ }^{36}$ and should not pursue the maximum protection of monopolistic rents as both the U.S. PTO and the WTO seem to be doing. It should, rather, search for the minimal common denominator, allowing for institutional and technological diversity and for distinctive developmental strategies (Boyle 2004, 2008). It should take into account the asymmetries in the distance to the "development frontier" among countries and regions, echoing Joseph Stiglitz's recent, and wise, remark that "Intellectual property is certainly important, but the appropriate IPR system for an emerging country is different than the IPR system best fitting already developed nations" (Stiglitz 2005). ${ }^{37}$

Health and the Department of Agriculture (Weiss, 2009). The fact they are not properly coordinated doesn't mean the potential for a cross-cutting agency is not there. On the contrary: the US is already half-way there.

${ }^{36}$ It should not, therefore, be framed as Coriat, Cimoli, and Primi indicate in a just-released paper, as an American "export": it is essential to note that recent (dramatic) changes in IP law have been strongly embedded in the specificities of an American patent law that is predicated on a common-law regime wherein the essential criterion for patentability is the "utility" the invention is deemed to have. Utility, a property that refers to products of "useful arts," basically involves industrial and commercial advances enabled by this invention. Under these conditions, in my opinion, the aforementioned change was in fact that suddenly it was enough to relax or change the meaning of the word "utility" for non-patentable areas to become patentable (Coriat, Cimoli, and Primi, 2005, p. 4).

${ }^{37}$ One of the main reasons for that, although certainly not the only one, is that the big pharmaceutical 
From an evolutionary-policy perspective, the key issue to deal with is how to separate innovation-rooted profits, which should be rewarded but understood as windfalls (dependent on continuous innovation), from legal monopoly-granted rents, which should be eliminated or, at least, closely monitored and curtailed.

None of these policy prescriptions will be achieved without a huge dose of "strategic state action," and most of them will require a high degree of international cooperation. This is an uneasy task; nonetheless, the expected result, to which this paper intends to be a small contribution, will be a theory-policy framework linking, conceptually, market features to innovation and Schumpeterian competition, and competition policies to intellectual property rights' management, which will allow room for catching-up initiatives and for the (re)construction of development strategies.

\section{REFERENCES}

Anthony, S. 2000. Antitrust and Intellectual Property Law: From Adversaries to Partners. AIPLA Quarterly Review Vol. 28, Number 1.

Austin, I. 2009. Common Foundations of American and East Asian Modernization- From Alexander Hamilton to Junichero Koizumi. Select Publishing.

Bartokas, A., and S. Mani, eds. 2004. Financial Systems, Corporate Investment in Innovation and Venture Capital. E. Elgar.

Baumol, W. 1993. Entrepreneurship, Management and the Nature of Payoffs. MIT Press.

Baumol, W. 2002. The Free-Market Innovation Machine. Princeton University Press.

Benkler, Y. 2003. Freedom in the Commons: Towards a Political Economy of Information. Duke Law Journal. No. 52.

Benkler, Y. 2006. The Wealth of Networks. Yale University Press.

Best, M. 2001. The New Competitive Advantage. Oxford University Press.

Block, F. 2008. "Where do Innovations Come From? Transformations in the U.S National Innovation System - 1970-2006”. Research paper for The Ford Foundation, Grant \# 1075-1307.

Bork, R. 1993. The Antitrust Paradox. Free Press.

Boyle, J. 2003. The Second Enclosure Movement and the Construction of the Public Domain. Available at http://www.law.duke.edu/boylesite/.

Boyle, J. 2004. Manifesto on the Future of WIPO. Available at http://www.law.duke.edu/boylesite/.

Boyle, J. 2008.The Public Domain. Yale University Press.

Brynjolfsson and Kahin, [eds. 2002. Understanding the Digital Economy. MIT Press.

Burlamaqui, L. 2000. Evolutionary Economics and the Role of State. In Burlamaqui, Castro, Chang, eds. Institutions and the Role of the State: New Horizons in Institutional and Evolutionary Economics. E. Elgar.

Burlamaqui L. 2009 a. "Innovation, Competition Policies and Intellectual Property -An Evolutionary Perspective and its Policy Implications" in The Development Agenda; Global Intellectual Property and Developing Countries, edited by Neil Netanel and published by Oxford University Press (2009).

Burlamaqui, L. 2009. b. Notes on Knowledge Governance. The Ford Foundation (Unpublished).

companies perform obscene price discrimination among nations (cf. Varian, Farrel, and Shapiro, 2004, p. 52) and almost always refuse to engage in poor and emerging countries' public policies oriented toward health care. 
Burlamaqui, L., and A. Proença. 2003. "Inovação, Recursos e Comprometimento: Em Direção a uma Teoria Estratégica da Firma.” Revista Brasileira de Inovação Ano 1, Vol. 3.

Carlton, D., and R. Gertner. 2002. Intellectual Property, Antitrust and Strategic Behavior. NBER Working Paper, No. 8976.

Chang, H. J. 2002. Kicking Away the Ladder. Anthem Press.

Cimoli, M., G. Dosi, R. Nelson, and J. Stiglitz. 2005. A Note on the Institutions and Policies Shaping Industrial Development. Paper presented at the IPD meeting, Rio, March 17-18.

Cimoli, M., and Primi, A. 2007. Technology and Intellectual Property: taxonomy of contemporary markets for knowledge and their implications for development.

Coriat, B., M. Cimoli, and A. Primi. 2005. Intellectual Property Right Regimes: Incentives and Constraints for Technological and Industrial Development. Paper presented at the IPD meeting, Rio, March 17-18.

De Long, B. 2000. The Dilemma of Antitrust - A Short History. Available at http://econ161.berkeley. edu/.

Dixon, P., and C. Greenlalgh. 2002: The Economics of Intellectual Property: A Review to Identify Themes for Future Research. CRIC, Manchester.

Dobbin, F., ed. The Sociology of the Economy. Russell Sage Foundation.

Drahos, P., and J. Braithwaite. 2002. Information Feudalism. The New Press.

Drechsler, W. 2005. The Rise and Demise of the New Public Management. Post-autistic Economics Review, Issue 33, September 14, pp. 17-28, http://www.paecon.net/PAEReview/issue33/Drechsler33.htm.

Ellig, J., ed. 2001. Dynamic Competition and Public Policy: Technology, Innovation, and Antitrust Issues. Cambridge University Press.

Evans, P. B. 1995. Embedded Autonomy: States and Industrial Transformation. Princeton University Press.

Evans, P. B. 2005. The New Commons vs. the Second Enclosure Movement: Comments on an Emerging Agenda for Development Research. Forthcoming in Studies in Comparative International Development.

Fong, G. 2001. Arpa Does Windows: The Defense Underpinning of the PC Revolution. Business \& Politics Vol. 3, Number 3 (November).

Hahn, F. 1984. Equilibrium and Macroeconomics. MIT Press.

Hovenkamp, H. 1999. Federal Antitrust Policy. West.

Jaffe, A., and J. Lerner. 2002. Innovation and Its Discontents: How Our Broken Patent System Is Endangering Innovation and Progress, and What to Do About It. Princeton University Press.

Jolly, A., and J. Philpott, eds. 2004. A Handbook of Intellectual Property Management. Kogan Page.

Kwoka Jr., J., and L. White, eds. 1999. The Antitrust Revolution. Oxford University Press.

Lachmann, L. 1986. The Market as an Economic Process. Blackwell.

Landes, W., and R. Posner. 2003. The Economic Structure of Intellectual Property Law. Belknap Press.

Langlois, R. 2001. Technological Standards, Innovation and Essential Facilities: Towards a Schumpeterian Approach. In J. Ellig, ed. Dynamic Competition and Public Policy: Technology, Innovation, and Antitrust Issues. Cambridge University Press.

Mazzoleni, R., and R. Nelson. 1998: The Benefits and Costs of Strong Patent Protection: A Contribution to the Current Debate. Research Policy Vol. 27.

Menell, P. 1999. Intellectual Property: General Theories. Working Paper, Berkeley Center for Law and Technology.

McCraw, T. 1984. Prophets of Regulation. Harvard University Press.

Mitchell, W., and R. Simmons. 1994. Beyond Politics - Markets, Welfare and the Failure of Bureaucracy. Westview Press.

Moglen, E. 2003. Freeing the Mind: Free Software and the Death of Proprietary Culture, Fourth Annual Technology and Law Conference, University of Maine Law School, Portland, June 29. 
Nee, V., and R. Swedberg, eds. 2005. The Economic Sociology of Capitalism. Princeton University Press.

Nelson, R. 1996. The Sources of Economic Growth. Harvard University Press.

Nelson, R., et al. 2004. Ivory Tower and Industrial Innovation: University-Industry Technology Transfer Before and After the Bayh-Dole Act in the United States. Stanford University Press.

Nelson, R., et al. 2005. A Program of Study of the Processes Involved in Technological and Economic Catch Up. The Earth Institute/Columbia University.

Nelson, R. 2007. “ Building Effective Innovation Systems versus dealing with Market Failures as Ways of Thinking About Technology Policy”. Unpublished Draft.

Noll, R. 2004. The Conflict over Vertical Foreclosure in Competition Policy and in Intellectual Property Law. Stanford Institute for Economic Policy Research, Working Paper No. 03-22.

Plant, A. 1934. Selected Economic Essays and Addresses.

Posner, R. 2002 [1976]. The Economic Analysis of Law. Aspen Publishers.

Reinert, E. 2007. How Countries Got Rich ... and Why Poor Countries Stay Poor. Constable Books.

Roland, A. 1983-1993. Strategic Computing: DARPA and the quest for Machine Intelligence. MIT Press.

Ruttan, V. 2006. Is War Necessary for Economic Growth? Oxford University Press.

Scherer, F. 1994. Competition Policies for an Integrated World Economy. The Brookings Institution.

Scherer, F. 1996. Industry Structure, Strategy and Public Policy. Harper Collins.

Schiff, E. 1971. Industrialization without National Patents. Princeton University Press.

Schumpeter, J. 1997 [1934]. The Theory of Economic Development. Transaction Publishers.

Schumpeter, J. 1994 [1942]. Capitalism, Socialism and Democracy. Routledge.

Shapiro, C., and H. Varian. 1999. Information Rules. HBS Press.

Shelby, H. 2000. A General Theory of Competition. Sage Books.

Smelster, N., and R. Swedberg, eds. 2005. The Handbook of Economic Sociology. Princeton University Press.

Stiglitz, J. 2005. “Erros e acertos da propriedade intelectual.” In O Globo, August 29.

Technology Review. 2005 (June). Intellectual Property Issue. MIT Press.

Teece, D. 2000. Managing Intellectual Capital. Oxford University Press.

Teece, D., and T. Jorde, eds. 1992. Antitrust, Innovation and Competitiveness. Oxford University Press.

Varian, H., J. Farrel, and C. Shapiro. 2004. The Economics of Information Technology. Cambridge University Press.

Vaughn, K. 1994. Austrian Economics in America - The Migration of a Tradition. Cambridge University Press.

Weber, M. 1922 [ 1976]. Economy and Society. Berkeley University Press.

Weiss, L. 2007. Governing the Market for America. Research paper for The Ford Foundation, Grant \# $1075-1307$.

Weiss, L. 2008: 'Crossing the Divide: From the Military-Industrial Complex to the Development-Procurement Complex'. Paper presented at the Berkeley

Workshop on 'The U.S. as a Hidden Developmental State', UC Berkeley, 19-21 June.Weiss, L 2009: The State in the Economy: Neoliberal or Neoactivist? Paper presented at the workshop "Innovation Policies in Hard Times", Rio de Janeiro, September, 2009.

Wells, W. 2002. Antitrust o the Formation of the Postwar World. Columbia University Press.

Wu, L. ed. 2004. Economics of Antitrust: New Issues, Questions, and Insights. NERA Economic Consulting. $</ \mathrm{REF}>$. 